FITRIA ANINDHITA H. WIBOWO

\title{
THE IMPLICATION OF THE PRECAUTIONARY PRINCIPLE ON INTERNATIONAL TRADE
}

\author{
LLM RESEARCH PAPER \\ LAWS 544 TOPICS IN ENVRONMENTAL LAW
}

FACULTY OF LAW

TE WHARE WANANGA O TE OPOKO O TE IKA A MAUI

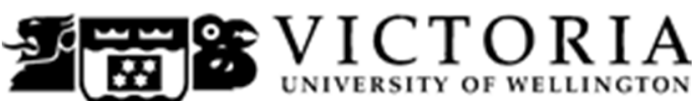

2014 


\section{Contents}

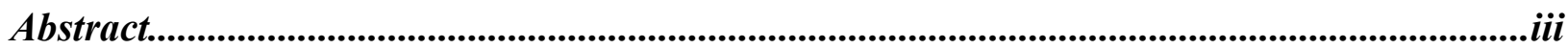

I INTRODUCTION

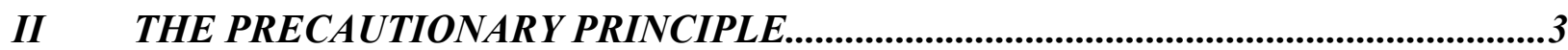

A The Origin and Nature of the Precautionary Principle.................................................3

B Application of the Precautionary Principle.......................................................................5

C Legal status of the Precautionary Principle....................................................................8

III THE PRECAUTIONARY PRINCIPLE IN INTERNATIONAL TRADE LAW...........9

A Precaution in International Trade Law................................................................9

B Implications of the Precautionary Principle on International Trade...........................11

C Conflicts between Precautionary Principle and WTO Rules....................................13

D Dispute Cases and the relevant WTO Agreements.................................................16

IV RECONCILING THE PRECAUTIONARY PRINCIPLE AND INTERNATIONAL

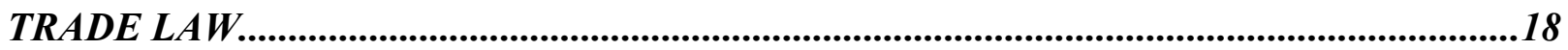

A Identifying Areas of Challenges...........................................................................18

B Addressing Challenges and Recommendations...................................................20

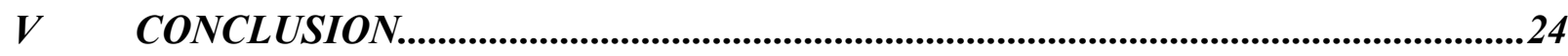

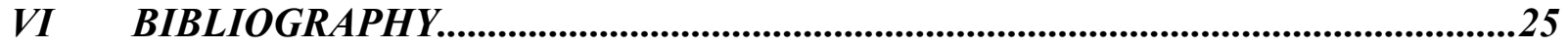




\begin{abstract}
This paper looks at the origin and nature of the precautionary principle as an emerging principle in international law that arises as a response to the impacts of human activities on the environment. As a chosen focus, this paper discusses the implication of the precautionary principle on international trade by looking at its relationship and interaction with international trade law under the World Trade Organization. This paper explores the consistency and conflicts between the precautionary principle and the rules under the WTO Agreements by examining the different and possibly similar values underlying both. This paper discusses the problem areas where the precautionary principle can conflict with WTO rules as well as explore areas where they can be made to comply with each other.
\end{abstract}

\title{
Word length
}

The text of this paper (excluding abstract, table of contents, footnotes, and bibliography) comprises 7534 words.

\section{Subjects and topics}

Precautionary Principle

International Trade (WTO) Law 


\section{Introduction}

In an ideal world, trade and environmental rules are complementary and mutually reinforcing. In principle, trade and environmental treaties or agreements are supportive of one another, alluding that the arising obligations do not conflict, outrank, or negate each other. It even goes as far as to encourage cooperation and coordination, and to synchronize possible discrepancies. In reality this may prove a challenging task to carry out. Reconciling trade and environmental rules have been the subject of considerable debate and discussion for a long time, the result of which remains uncertain.

It is recognizable that trade and environmental treaties are established with different objectives and underlying purposes in mind. They are also subject to the conditions and circumstances during which they were formulated. These can include factors such as economic, social, and cultural situations. Different times demand different responses and measures to certain problems. Hence, it is not uncommon that the principles contained in trade and environmental agreements do not complement one another.

In the recent past, there has been a mounting concern on the impact of trade on the environment. This has been amplified by the growing interconnectedness of nations due to globalization. Cross-border trade has been advancing at a rapid rate, resulting in ever-growing interdependence and expansive supply chain. The impact of trade on the environment could be wide-spread, it could spill over or occur in a territory other than the origin of the products. There has been efforts to address this concern, all at the national, regional, and international levels. These efforts have resulted in the emergence of certain movements or principles, among which is the Precautionary Principle.

As environmental damage grew more apparent, there was an increasing recognition that scientific method does not necessarily give certainty to the evidence of the impact of human activities on the environment. ${ }^{1}$ The precautionary principle evolved from the growing acknowledgement that scientific certainty often comes too late to generate effective legal and

\footnotetext{
${ }^{1}$ National Toxics Network Inc. "The Precautionary Principle Gets Real" $<$ www.oztoxics.org $>$ at 1.
} 
policy responses to potential environmental threats. ${ }^{2}$ It is seen as a useful tool for a more systematic response to the problem of scientific uncertainty in environment decision-making. ${ }^{3}$ It remains however the subject of debate in the context of trade and how it interacts with the principles and rules of multilateral trade law, in this case the World Trade Organization (WTO).

The precautionary principle has significant implications on international trade and there is a debate whether it is consistent with and what impacts it may have on the rules of the WTO. ${ }^{4}$ Furthermore, there is an ongoing discussion on the situations that may trigger the application of the precautionary principle with regard to the WTO. As one may be aware, the WTO has its own approach to addressing environmental concerns, and its rules do not encompass the precautionary principle. The WTO has roots which date back to the GATT, first established in 1947, and thus has not accommodated the precautionary principle which is a relatively new concept. $^{5}$

The WTO as an international legal sub-system is not isolated from other sources of public international law, and if the precautionary principle has the potential to be such, then the WTO should accommodate it in its system. ${ }^{6}$ The idea of precaution is not entirely absent in the WTO, yet it takes a different form and is governed by a different set of rules. The question is whether the precautionary principle can be compatible with the rules of the WTO. Although some would argue that the ideas are overlapping, it is still nearly impossible to reconcile the two. This mainly owes to the current definitions of the Precautionary Principle and the underlying core of the WTO which is trade liberalization. ${ }^{7}$

Notwithstanding such an argument, current environmental conditions will drive countries and governments to make changes in their policies, and the precautionary principle seems to become an increasingly acceptable solution. Given that, there is a need to harmonize between

\footnotetext{
${ }^{2}$ Markus W. Gehring and Marie-Claire Cordonier Segger "Precaution in World Trade Law: The Precautionary Principle and its Implications for World Trade Organization” (2002) Research Paper <www. cisdl.org>.

${ }^{3}$ Above $n$ 2, at 6.

${ }^{4}$ Lawrence A. Kogan "The Precautionary Principle and WTO Law: Divergent Views toward the Role of Science in Assessing and Managing Risk" (2004) Seton Hall Journal of Diplomacy and International Relations $<$ www.kms2.isn.ethz.ch> at 77.

5 Natasja Borjeson "WTO, GMO and the Precautionary Principle-the conflict between trade liberalization and environmental protection" (2004) Soderton Hogskola University College <www.diva-portal.org>.

${ }^{6}$ Gehring, above $\mathrm{n} 2$, at

${ }^{7}$ Halina Ward "Science and Precaution in the Trading System" (2002) Seminar Note <www.iisd.org>.
} 
international trade law and environmental law at some point. There are several options which can done be to achieve this and it may be a daunting task, but it does seem inevitable. This paper attempts to look at the nature of the precautionary principle and the rules of the WTO, the different and possibly similar values underlying both, and explore areas where they can be made to comply with each other.

\section{The Precautionary Principle}

\section{A The Origin and Nature of the Precautionary Principle}

The concept of the precautionary principle originated as a specific principle of environmental policy in Germany, the 'Vorsorgeprinzip', which is to be found in the 1974 Federal Emission Protection Act concerning an air pollution control law and later used by policymakers to address decision-making surrounding uncertainties of air pollution policies. ${ }^{8}$ The core idea of the precautionary principle is that where human activities may have damaging effects on the environment, decision-makers should not wait for full scientific proof before taking appropriate protective measures. ${ }^{9}$

At the national level, the application of the precautionary principle remains fragmented, but at the international level, particularly in international environmental law and policy, many formulations can be found. ${ }^{10}$ Article 15 of the Rio Declaration 1992 states that 'in order to protect the environment, the precautionary approach shall be widely applied by States according to their capabilities. Where there are threats of serious or irreversible damage, lack of scientific certainty shall not be used as a reason for postponing cost-effective measures to prevent environmental degradation'. ${ }^{11}$

If we look further, the concept of precaution is accommodated in a number of other international agreements. In the Kyoto Protocol ${ }^{12}$, Article 3.3 provides that Parties should take precautionary measures to anticipate, prevent or minimize the causes of climate change and

\footnotetext{
${ }^{8}$ Gehring, above n 2, at 6.

${ }^{9}$ Ward, Above n 7, at 2.

${ }^{10}$ Above $\mathrm{n} 7$, at 2.

${ }^{11}$ United Nations Rio Declaration on Environment and Development 1992.

12 Kyoto Protocol to the United Nations Framework Convention on Climate Change (open for signature 11 December 1997, entered into force 16 February 2005).
} 
mitigate its adverse effects. The Cartagena Protocol on Biosafety ${ }^{13}$ is considered to contain the broadest expression of the precautionary principle and refers to the precautionary approach as contained in the Rio Declaration. The Protocol emphasizes that the lack of scientific certainty on the potential dangers to the environment or human health shall not prevent Parties from taking decisions with regard to imports of living modified organisms.

The Stockholm Convention ${ }^{14}$ refers to precaution in a number of its provisions. It acknowledges that all Parties is concerned with precaution and takes into account the precautionary approach as set out in the Rio Declaration with the objective to protect human health and the environment. As regards scientific uncertainty, it stipulates that Parties shall decide in a precautionary manner on measures concerning chemicals. The Montreal Protocol ${ }^{15}$ in its preamble states that it takes precautionary measures to control substances that deplete the ozone layer and notes such measures which have been implemented. Furthermore, the Rotterdam Convention ${ }^{16}$ requires export notifications that contain information on precautionary measures to reduce exposure to and emission of the chemicals.

In this context, it can be perceived that the precautionary principle constitutes an emerging principle in international environmental law and as such it may become a general principle of international environmental law. ${ }^{17}$ There is also a conception that it can become a customary international law if it consists the regular practices and rules followed by states. In this case it needs to demonstrate a consistent practice by states within their borders and in their interaction with other states as reflected by court decisions, legislation and diplomatic practice, as well as the acceptance as law of such acts. ${ }^{18}$

\footnotetext{
13 The Cartagena Protocol on Biosafety to the Convention on Biological Diversity (open for signature 29 January 2000, entered into force 11 September 2003).

14 The Stockholm Convention on Persistent Organic Pollutants (open for signature 22 May 2001, entered into force 17 May 2004).

15 The Montreal Protocol on Substances that Deplete the Ozone Layer (open for signature 16 September 1987 , entered into force 1 January 1989).

16 The Rotterdam Convention on Prior Informed Consent for Certain Hazardous Chemicals and Pesticides in International Trade (open for signature 10 September 1998, entered into force 24 February 2004).

${ }^{17}$ Ward, above n 7, at 4.

${ }^{18}$ Kogan, above n 4, at 101.
} 
From an environmental perspective, the precautionary principle or precautionary approach supports taking protective action before full scientific evidence of risks. ${ }^{19}$ There are examples of man-made risks and where scientific certainty is lacking, decision-makers often did not take precautions and failed to take anticipatory actions in due time, resulting in considerable harm over a long time-span until scientific certainty is established. ${ }^{20}$ The Precautionary Principle is to be distinguished from preventive actions and can only be invoked when there is insufficient, inconclusive or imprecise scientific data which leads to the uncertainty of risks or hazard. The risks perceived would have to be reasonable or too high to be imposed on the environment or human health. ${ }^{21}$

An important characteristic of the precautionary principle is that legislators may shift the burden of proof to the parties who intend to conduct the activities which may affect the environment. These parties are to establish that their activities are safe and will not adversely impact the environment or public health. Legislators, by way of precaution, can require that activities be deemed hazardous until proven otherwise, and place the burden of proof on the business community, that is the producer, manufacturer, or importer to show that it is safe. ${ }^{22}$ In other words, as long as risks to the environment or human health cannot be established with sufficient certainty, the executive is not legally entitled to authorize the activities. ${ }^{23}$

\section{B. Application of the Precautionary Principle}

The most common inquiry about the precautionary principle is on how it is applied or what can trigger the application of the principle. Wagner in his paper describes the situation as such:

...the ability to take action in order to avoid anticipated harmful effects, is difficult to predict in the abstract and without reference to a concrete situation. Guiding principles are-again-the principle of proportionality and non-

\footnotetext{
${ }^{19}$ Ward, Above n 7, at 2.

${ }^{20}$ Miriam Haritz An Inconvenient Deliberation: The Precautionary Principle's Contribution to the Uncertainties Surrounding Climate Change Liability (Wolters Kluwer, Alphen aan den Rijn, 2011).

21 European Union Communication on Precautionary Principle "Commission adopts Communication on Precautionary Principle (2 February 2000) <www.gdrc.org $>$.

${ }^{22}$ Gehring, above $\mathrm{n} 2$, at 10 .

23 Above $n$ 2, at 11 .
} 
discrimination. In more concrete terms, measures must be commensurate with the anticipated harm... ${ }^{24}$

In determining when and how the principle can be applied, it needs to be considered in the context of a more generic risk management framework with clear guidelines that provide a systematic approach to setting the best course of action under uncertainty. ${ }^{25}$ The triggering factor of serious threat or irreversible damage is difficult to define and therefore has to be evaluated on a case-by-case basis. $^{26}$

Precaution goes to the core consideration of environmental risk, particularly chemical risk $^{27}$ because scientific method does not guarantee certainty and uncertainty inevitably arises in risk assessment. ${ }^{28}$ Data and information on some risks may be well documented and understood while others remain highly uncertain ${ }^{29}$ due to incomplete information, measurement errors and variability, risk model limitations or the range of discretionary judgments incorporated into the standard risk assessment. ${ }^{30}$

To put simply, the precautionary principle functions based on two variables: a triggering condition which consists of the implication of harm and the established degree of knowledge; and the precautionary approach or the reaction that follows. ${ }^{31}$ Furthermore, the level of scientific uncertainty and the specific threats which require precautionary action, and the scope of the actions to be taken are important in determining the key elements of the precautionary principle. ${ }^{32}$ Herwig states that the precautionary principle expands the requirement for normative

\footnotetext{
${ }^{24}$ Markus Wagner "Taking Interdependence Seriously: The Need for a Reassessment of the Precautionary Principle in International Trade Law" (10 September 2012)<www.papers.ssrn.com> at 729.

${ }^{25}$ Linda Cameron "Environmental Risk Management in New Zealand-Is There Scope to Apply A More Generic Framework?" (July 2006) New Zealand Treasury Policy Perspectives Paper 06/06, at 1.

${ }^{26}$ Above $\mathrm{n} 25$, at 6 .

${ }^{27}$ National Toxics Network Inc., above n 1, at 11.

28 enHealth Council "Framework for Environmental Health Risk Assessment" (April 2000) Department of Health and Aged Care, Canberra, as cited in National Toxics Network Inc., above n 1, at 11.

${ }^{29}$ Wiener JB and Rogers MD "Comparing precaution in the United States and Europe" (2002) Journal of Risk Research, as cited in National Toxics Network Inc., above n 1, at 11.

${ }^{30}$ L. Susskind and P. Field Dealing with An Angry Public, The Mutual Gains Approach to Resolving Disputes (The Free Press, New York, 1996), as cited in National Toxics Network Inc., above n 1, at 11.

${ }^{31}$ M. Athensuu Rationale for Taking Precautions: Normative Choices and Commitments in the Implementation of the Precautionary Principle, Risk \& Rationalities Conference Proceedings (2007) as cited in Haritz, above n 20, at 82.

32 A. Holdway Reducing Uncertainty: The Need to Clarify the Key Elements of the Precautionary Principle (2008), as cited in Haritz, above n 20, at 83.
} 
and evaluative justifications for setting protection levels against risk because a broader array of scientific evidence has to be considered by decision-makers. ${ }^{33}$

When invoking the principle, it is equally important to identify potential negative effects which may arise from such action. Often times the effects can be identified by conducting scientific research and followed by risk assessment. ${ }^{34}$ Decision makers then decide whether to act or not based on the available information of all factors to be considered. The decision not to act can also be considered a response, and the recourse to the precautionary principle does not necessarily mean adopting final instruments designed to produce legal effects. ${ }^{35}$ There are various courses of actions which can be carried out as a result of relying on the principle, such as decisions to fund a research program or to inform the public about the possible adverse effects of a product or procedure. ${ }^{36}$ As such, the precautionary principle can be considered as a reasonable policy options for decisions being taken in a situation of scientific uncertainty after assessments have been carried out, that could result in various options and not just total bans. ${ }^{37}$

In short, the precautionary principle is an instrument used for regulating uncertainty, providing guidance in the evolution and practical application of environmental law. ${ }^{38}$ It is flexible and does not dictate a specific regulatory measure, but allows for a variety of measures to be taken. ${ }^{39}$ The guiding principles for the ability to take action in order to avoid anticipated harmful effects are the principle of proportionality and non-discrimination, where measures must be commensurate with the anticipated harm and should not be more burdensome than necessary, consistency, and cost-benefit analysis. ${ }^{40}$

\footnotetext{
${ }^{33}$ Alexa Herwig "The Precautionary Principle in Support of Practical Reason: An Argument Against Formalistic Interpretations of the Precautionary Principle" in Constitutionalism: Multilevel Trade Governance and International Economic Law" (Christian Joerges and Ernst-Ulrich Petersmann eds.) Hart Publishing, Portland, 2011, at 305.

${ }^{34}$ Gehring, above $\mathrm{n} 2$, at 9.

${ }^{35}$ Above $\mathrm{n} 2$, at 9 .

${ }^{36}$ Above $\mathrm{n} 2$, at 9 .

${ }^{37}$ Above n 2, at 9.

${ }^{38}$ Haritz, above n 20, at 79.

${ }^{39}$ Wagner, above $\mathrm{n} 24$, at 736 .

${ }^{40}$ Above $n 24$, at 725 .
} 


\section{Legal status of Precautionary Principle}

One of the significance of the precautionary principle lies in its challenge to traditional legal systems, many of which are permeated by the need for certainty. ${ }^{41}$ Principles in nature is legally binding and become indirectly applicable through forming the basis of specifically formulated rules, thereby gaining legal weight and have a high moral content, providing the link between an environmental ideal and applicable and enforceable legal rules. ${ }^{42}$ Principles in international environmental law often fall under the category of soft law and are not regarded as binding because of the difficulty of reaching consensus in such a highly disputed and relatively recent field as environmental protection. ${ }^{43}$ However, soft law may evolve into hard law through customary practice, and even if a principle remains soft, it will still be observed. ${ }^{44}$

The legal value of the principle experiences differences in judicial review where courts will check if such principle was applied correctly with regard to invocation by decision-makers to justify action. On the other hand, where decision-makers have refrained from taking action, courts have been rather reluctant to review the lack of application of the principle, and consider the decision to apply or non-application of the principle a political matter. ${ }^{45}$ The application of the precautionary principle is particularly difficult from a legal point of view when it comes to the standard of proof required, the threshold of which may vary depending on the areas concerned, the perception of judicially acceptable scientific data, or the plausibility of threat and causality. ${ }^{46}$

The perception by some that the precautionary principle is a mere policy and a true legal principle by others is due to the lack of a concrete definition, which owes to the varying types of practical implementation and content. ${ }^{47}$ On the other hand, these variations can also be considered a necessity in responding to the diversity of legal cultures, which is why they reflect

\footnotetext{
${ }^{41}$ Nicolas de Sadeleer Implementing the Precautionary Principle (Earthscan, London, 2007) at 4.

${ }^{42}$ G. Winter "The Legal Nature of Environmental Principles in International, EC and German Law (2003); J. Verschuuren Principles of Environmental Law: The Ideal of Sustainable Development and the Role of Principles of International, European, and National Environmental Law (2003) Umweltrechliche Studien Nr. 30, Nomos Verlag: Baden Baden, as cited in Haritz, above n 20, at 84.

${ }^{43}$ Vershuuren, above $\mathrm{n} 42$, at 85.

${ }^{44}$ Above $\mathrm{n} 42$, at 85 .

${ }^{45}$ Winter, above $\mathrm{n} 42$, at 85

${ }^{46}$ Haritz, above $n$ 20, at 86 .

${ }^{47}$ Above n 20, at 87.
} 
the worldwide representation of the precautionary principle as a relative success story. ${ }^{48}$ All in all, there is certainly recognition of the precautionary principle at the national and international level.

\section{Precautionary Principle in International Trade Law}

\section{A Precaution in International Trade Law}

In discussing international trade law, this paper refers to the rules of the World Trade Organization (WTO). The WTO is the only organization dealing with international trade and as such has one of the most effective dispute settlement mechanisms. The WTO is a rule-making body which enforces and oversees the implementation of trade rules under its agreements. The WTO's foundation is the Marrakesh Agreement establishing the $\mathrm{WTO}^{49}$ and its rules are contained in its sectorial agreements (the Agreements) including on sanitary and phytosanitary measures (SPS) and technical barriers to trade (TBT).

Basically the WTO sets the minimum standard for the conduct of trade between countries which must be observed when implementing national laws, including on environmental protection. The WTO's basic principle is free, fair, and equitable trade among its Member States, and promotes trade liberalization and open market access for all Member States. Member States are not to implement measures that may constitute as barriers and have distorting effects on trade. The lack of compliance with its rules is deemed to potentially impair or nullify benefits accrued by other Member States. ${ }^{50}$

Trade and environmental issues was agreed to be discussed as part of the Doha Round, which started in 2001, particularly with emphasis on negotiating and clarifying the relationship between WTO rules and existing trade obligations specified in multilateral environmental agreements (MEAs). ${ }^{51}$ There was recognition by the Member States that the undertaking of the

\footnotetext{
48 E. Fisher Precaution, Precaution Everywhere: Developing a “Common Understanding” of the Precautionary Principle in the European Community (2002) Maastricht Journal of European and Comparative Law Vol.9 No.1, as cited in Haritz, above $\mathrm{n} 20$, at 87.

${ }^{49}$ Marrakesh Agreement Establishing the World Trade Organization LT/UR/A/1 (signed 15 April 1994, entered into force 1 January 1995).

${ }^{50}$ Edith Brown Weiss, John Howard Jackson and Nathalie Bernasconi-Osterwalder eds. Reconciling Environment and Trade (2nd ed, Martinus Nijhoff, USA, 2008) at 17.

${ }^{51}$ Kogan, above n 4, at 95.
} 
concept of sustainable development by the international community has put demands on the economic development to include an aim for a sustainable use of resources of the world. ${ }^{52}$ However, Kogan further added that at least two WTO Agreements were specifically designed to prevent Member States from enacting technical regulations and/or standards that constitutes unnecessary obstacles to trade: 1) the SPS Agreement relating to food and plant-based products, and 2) the TBT Agreement relating to all other non-food and non-plant products. These two agreements generally recognize that standards and regulations can be used as disguised non-tariff barriers.

The SPS Agreement requires Member States to conduct an objective risk analysis that must include a science-based risk assessment of a certain product or substance in light of a specifically identified and ascertainable risk in order to justify their regulatory actions, especially when international standards do not exist. ${ }^{53}$ Similarly, the TBT Agreement requires that national or regional legislations be based on relevant objective performance-oriented standards developed by recognized international standards bodies and to ensure that regulations and standards are not prepared, adopted or applied with a view to create unnecessary obstacles to international trade. ${ }^{54}$

The WTO system as an international legal sub-system is not isolated from the widespread sources of public international law and as such the emergence of the precautionary principle as a customary international law should be taken into account in international trade law decisionmaking. ${ }^{55}$ While none of the WTO Agreements explicitly mentions the precautionary principle, different provisions can be considered as incorporating the precautionary approach ${ }^{56}$, such as the SPS Agreement. There is a general recognition of the precautionary principle in international law and is beginning to be brought into WTO case law with mixed results. ${ }^{57}$

\footnotetext{
${ }^{52} \mathrm{M}$. Mathee and D. Vermeesh "Are the Precautionary Principle and the International Trade of Genetically Modified Organisms Reconcilable?" (2000) Journal of Agricultural and Evironmental Ethics No. 12, as cited in Borjeson, above $\mathrm{n}$ 5, at 27.

${ }^{53}$ Lawrence Kogan "Looking Behind the Curtain: The Growth of Trade Barriers that Ignore Sound Science"; Lawrence Kogan "Unscientific 'Precaution': Europe's Campaign to Erect New Foreign Trade Barriers", as cited in Kogan, above $\mathrm{n} 4$, at 96.

${ }^{54}$ Agreement on Technical Barriers to Trade LT/UR/A-1A/10 (signed 15 April 1994, entered into force 1 January 1995).

${ }^{55}$ Gehring, above n 2, at 27.

${ }^{56}$ Above $\mathrm{n} 2$, at 27.

${ }^{57}$ Above n 2, at 27.
} 


\section{B. Implications of the Precautionary Principle on International Trade}

Precaution is not unknown to the WTO, particularly in its application to public health. ${ }^{58}$ The debate is whether WTO Members can use the precautionary principle consistently with their WTO obligations. The debate has focused on concerns about the impact that such a principle could have on the marketability of future and emerging technologies and their potential use throughout the world. ${ }^{59}$ There is also a concern among Member states that such principle may be applied as disguised protectionism to protect ailing domestic industries. ${ }^{60}$ There are a few case laws which provide examples of how the use of the precautionary principle has affected international trade, as will be discussed later.

The WTO allows governments in pursuance of national health and other policy objectives to take measures to restrict trade ${ }^{61}$ in order to protect human, animal, or plant life or health. But it is important to keep in mind that the emphasis of the WTO Agreements is on how policies are pursued and in doing so Member States are to ensure that measures are applied in the leastrestrictive manner and must be proportionate to the objective sought. With regard to environmental and health concerns in the context of the WTO, the SPS Agreement is the most significant international trade treaty. But there is recognition that the application of precaution poses a challenge for regulatory action because of the uncertainty of risks surrounding a given hazard. ${ }^{62}$

The precautionary approach uses the least environmentally harmful way to achieve a particular public policy objective compared to the WTO of least trade-restrictive method. ${ }^{63}$ As such, the precautionary approach is perceived as defending environmental public health measures that are excessively trade restrictive and therefore, protectionist in nature. ${ }^{64}$ However, the SPS Agreement provides Member States with the right to adopt measures that are higher in SPS level than stipulated by international standards, guidelines or recommendations if there is

\footnotetext{
${ }^{58}$ Gehring, Above n 2, at 27.

${ }^{59}$ Kogan, above $\mathrm{n} 4$, at 98.

${ }^{60}$ Above $\mathrm{n} 4$, at 98.

${ }^{61}$ Gehring, above n 2, at 27.

${ }^{62}$ Above $\mathrm{n} 2$, at 27.

63 C. Saladin "Precautionary Principle in International Law" (2000) International Journal of Occupational and Environmental Health Vol.6 No. 4 October/December, as cited by National Toxics Network Inc., above n 1, at 5.

${ }^{64}$ National Toxics Network Inc., above n 1, at 5.
} 
scientific justification, thereby applying the level of protection, tolerance of risk, and degree of precaution that is appropriate for them. ${ }^{65}$ Furthermore, in the absence of sufficient evidence, Member States may provisionally adopt SPS measures on the basis of available pertinent information. ${ }^{66}$ In doing so however, Members are not to adopt measures in an arbitrary or discriminatory manner. ${ }^{67}$

An example of how the precautionary principle has affected international trade is the ECBiotech $^{68}$ case concerning a moratorium on approvals of biotech products, the approval of specific biotech products, and safeguard measures prohibiting the import/marketing of specific biotech products within the then European Community. The effect of this measure is to block EU market access to all exports of genetically modified food products that originated from the United States, Argentina, Canada and Mexico. Such attitude towards GMO is perceived to have generally encouraged a global anti-GMO movement and jeopardized the establishment of GMO research and development programs and the domestic sale of GMO products within Brazil and many African and Asian developing countries. ${ }^{69}$

In the challenge by the United States, the WTO Dispute Settlement Panel found that the EU measure was not applied to achieve the EC level of sanitary and phytosanitary protection and led to undue delay of final substantive approval decision. As such the Panel found that the EU acted inconsistently with the SPS Agreement. Similar measures or initiatives are feared by some to result in the formalization of precaution into an absolute principle, the objective of which is to eliminate almost all risk from everyday economic life. ${ }^{70}$ Such application of the precautionary principle is viewed to undermine the importance of classical risk assessment, impairs humankind's ability to innovate in the short and long term, and therefore clearly undesirable. ${ }^{71}$

\footnotetext{
${ }^{65}$ Agreement on the Application of Sanitary and Phytosanitary Measures LT/UR/A-1A/12 (signed 15 April 1994 , entered into force 1 January 1995), Article 3.3.

${ }^{66}$ Above n 60, Article 5.7.

${ }^{67}$ Above n 60, Article 5.5.

${ }^{68}$ European Communities - Measures Affecting the Approval and Marketing of Biotech Products WT/DS291/R, 29 September 2006 (Panel Report).

${ }^{69}$ Lawrence Kogan "Looking Behind the Curtain: The Growth of Trade Barriers that Ignore Sound Science" (May 2003) National Foreign Trade Council, as cited in Kogan, above n 4, at 98.

${ }^{70}$ Kogan, above $n$, at 101.

${ }^{71}$ Above $\mathrm{n}$, at 101 .
} 


\section{Conflicts between the Precautionary Principle and WTO Rules}

Another high profile case is the EC-Hormones ${ }^{72}$ concerning the ban on imports of meat from cattle to which bovine growth hormones had been administered for the purpose of promoting growth and prohibition of the use of hormones domestically and the domestic sale of any meat products from animals hormonally treated. The Directive concerned was aimed to protect consumer health and the environment from the possible hazard of animal meat treated with growth hormones. Even so, the EC measure was found to be inconsistent with specific provisions of the SPS Agreement and it was not sufficiently based on a risk assessment which must demonstrate a rational relationship with the measure.

This case highlighted the reality that currently there is still relatively small room to accommodate the idea of precaution within WTO rules. It seems that ultimately this kind of approach and the WTO rules are still almost impossible to reconcile. The WTO Appellate Body deciding the case stated that the precautionary principle may be regarded by some as a general principle of customary international law but that this appears less clear to them and noted that outside the field of international environmental law it still awaits authoritative formulation. ${ }^{73}$ It can be concluded that if a Member State was to rely on an interpretation of the precautionary principle that is broader than the provision of the SPS Agreement, it will be deemed to exceed WTO rules, and it will need to establish that the precautionary principle is a principle of customary international law or otherwise considered by a WTO panel to resolve a WTO dispute. ${ }^{74}$ Kogan further elaborated that:

\footnotetext{
...in order to establish the precautionary approach as a norm of customary international law, it must be shown that the texts of the SPS and the TBT Agreements reflect the intent and obligations of WTO Members to adopt the precautionary principle as a WTO treaty norm. Alternatively it must be demonstrated that WTO Members' understanding of the WTO treaty texts has evolved enough to accommodate the precautionary principle, and that WTO Members have actually adopted the precautionary principle as a matter of state regulatory and/or standard practice and custom in other fora (e.g., pursuant to the terms of a multilateral environmental treaty or as a matter of public international law. ${ }^{75}$
}

\footnotetext{
72 European Communities - Measures Concerning Meat and Meat Products WT/DS26/AB/R and WT/DS48/AB/R, 13 February 1998 (Appellate Body Report).

${ }^{73}$ Kogan, above n 4, at 101.

${ }^{74}$ Above $\mathrm{n}$ 4, at 101.

${ }^{75}$ Lawrence Kogan “Unscientific 'Precaution': Europe's Campaign to Erect New Foreign Trade Barriers”, as cited in Kogan, above n 4, at 102.
} 
The WTO can be quite rigid in enforcing its rules and that even environmental concerns cannot result in measures that are trade restrictive. The rules are established to accommodate free and fair trade rather than environmental protection. The ability to prove precautionary principle as a customary international law does not necessarily translate into its incorporation in the SPS and TBT Agreement. There also remains the question of compatibility between WTO rules and the rules of MEAs, even if they are intended to be mutually supportive and not conflict with one another. MEAs are fundamentally different in scope, only a few are concerned with trade. MEAs are often formulated to pursue a separate set of objectives than the WTO, and even if there is recognition of the inter-linkage with trade, the rules seldom coordinate with the rules of the WTO. It is also uncommon for an MEA to demand compliance through a dispute settlement procedure or to have a comprehensive dispute settlement mechanism and a highly effective body such as the WTO Dispute Settlement Body to implement it.

The precautionary principle can also be viewed in light of conflicting obligations that arise from MEAs and the WTO, in particular where the obligations under an MEA leads to the adoption of measures that could hamper trade. The WTO's mandate in identifying the relationship between trade and environment includes a focus on the relationship between the rules of the multilateral trading system and trade measures contained in MEAs. ${ }^{76}$ This mandate is currently being carried out in the Committee on Trade and Environment (CTE). ${ }^{77}$ Furthermore, it instructs Members to make recommendations where changes in the multilateral trading system are necessary with a view to enhancing interaction and mutual supportiveness between trade and environmental measures. Based on the current situation, it appears that the mandate has little improved the relationship between the WTO and MEAs.

Some would argue that the principles of international trade law have failed to catch up with the growing public concern that is associated with decision-making in the face of scientific uncertainty. ${ }^{78}$ Even with the provision of the GATT 1994, which includes a general exception ${ }^{79}$ that permits Member States to adopt measures deemed necessary to protect the environment, and in doing so derogate from their obligations provided that measures are applied consistently with

\footnotetext{
76 Decision on Trade and Environment (signed 15 April 1994, entered into force 1 January 1995).

${ }^{77}$ Doha Ministerial Declaration WT/MIN(01)/DEC/1 (2001).

${ }^{78}$ Ward, above $\mathrm{n} 7$, at 4.

${ }^{79}$ General Agreement on Tariffs and Trade 1994, Article XX.
} 
the non-discrimination principles, it still fails to draw a fair balance between trade and environmental policy objectives.

The precautionary principle interacts with WTO rules in three main ways: 1) when WTO rules have an impact on domestic regulation and whether balance can be established between trade and precautionary principle or how prepared is the WTO to look inside national measures and accord deference to the policy choices of Member States; 2) via the link between WTO rules and general principles of international law, as to what extent the WTO rules and dispute settlement should take the precautionary principle into account on the basis that it has become a general principle of international law; and 3) with regard to the burden of proof applied in WTO dispute settlement, as in how to ensure that WTO rules do not encourage exporting countries not to gather scientific evidence of risks associated with their exports or that trade is favored at the expense scientific assessment. ${ }^{80}$

The principle of 'special and differential treatment" ${ }^{\text {' }}$ contained in the WTO Agreements to address specific constraints faced by developing countries, in a way also complicates the incorporation of the precautionary principle into the WTO. In the spirit of free trade and integration of developing and least-developed countries into the multilateral trading system, Member States are encouraged to accord favorable treatment, special preferences and extended market access. An environmental measure adopted on the basis of a principle which has the potential of obstructing trade and reducing the benefit to these countries is seen as an opposition to the very foundation of the WTO.

Many consider that eventually it is necessary for the operation of WTO that it contains an effective set of provisions on the environment, but that at the time being there is still a real risk of abuse. ${ }^{82}$ In addition, Ward states that 'for the future, a major challenge for the WTO will be to avoid having effectively make determinations on 'right' and 'wrong' on the scale from risk identification and assessment through to risk management and scientific assessment. ${ }^{83}$ There may be a need for establishing guidelines on the precautionary principle and trade to prevent it

\footnotetext{
${ }^{80}$ Ward, above $\mathrm{n} 7$, at 5 .

${ }^{81}$ Doha Ministerial Declaration WT/MIN(01)/DEC/1 (2001), Paragraph 44.

${ }^{82}$ Ward, above $\mathrm{n} 7$, at 7 .

${ }^{83}$ Above n 7, at 7.
} 
from being utilized in support of protectionism, which involves seeking clarification between a number of environmental principles and the rules of the WTO. ${ }^{84}$

\section{Dispute Cases and the relevant WTO Agreements}

In previous sections the paper has illustrated a few cases which involve the application of the precaution in the face of uncertain impacts. A further explanation on the EC-Biotech case discussed whether Article 5.7 of the SPS Agreement which allows Member States to adopt SPS measures in the face of insufficient scientific evidence is regarded as an independent right or an exception. ${ }^{85}$ To be regarded as an independent right, a few conditions must be met which includes circumstances which permits behavior that would otherwise be inconsistent with the obligations. ${ }^{86}$ So it can be assumed that although Article 5.7 facilitates a precautionary approach, it is not a full embodiment of the precautionary principle. This is further confirmed by the Appellate Body findings in the Japan-Agricultural Products ${ }^{87}$ case concerning Japanese measures to quarantine treatment for certain agricultural products. The Appellate Body decided that the measure could not be maintained unless the "lack" of evidence is overcome as a WTO Member invoking this provision must seek to obtain the additional information necessary for a more objective assessment of the risk and that any measure must be reviewed within a reasonable period of time. ${ }^{88}$

Japan had claimed that insufficient evidence had been at issue for 20 years which the Appellate Body did not consider to be a reasonable period of time (RPT). An RPT must be viewed depending on how easy it was to collect the additional information necessary for a review, so that it is determined both in terms of duration (in this case 20 years was too long) and in relation to the difficulties of the scientific research process in concluding the evidence. ${ }^{89}$

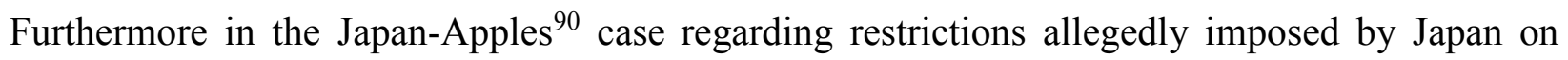

\footnotetext{
${ }^{84}$ Ward, above $\mathrm{n} 7$, at 7.

${ }^{85}$ Abdolhossein Shiravi and Azam Ansari "Precautionary Principle in the International Trade Regime: A Careful Look at the WTO SPS Agreement" <www.wbiconpro.com> at 6.

${ }^{86}$ Above $\mathrm{n} 85$, at 6.

${ }^{87}$ Japan - Measures Affecting Agricultural Products WT/DS76/AB/R, 19 March 1999 (Appellate Body Report).

${ }^{88}$ Wagner, above n 24, at 741.

${ }^{89}$ Christiane Gerstetter and Matthias Leonhard Maier "Risk Regulation, trade and international law: debating the precautionary principle in and around the WTO” (2005) Transtate Working Papers No. $18<$ www.econstor.eu> at 12.

${ }^{90}$ Japan - Measures Affecting the Importation of Apples WT/DS245/AB/R, 10 December 2003 (Panel Report).
} 
imports of apples from the United States, the restrictions were said to be necessary to protect against introduction of fire blight. The Appellate Body found that the measure was inconsistent with Articles 2.2, 5.7, and 5.1 of the SPS Agreement and that there must be an adequate relationship between the SPS measure applied and the scientific proof of the existence of harm. Japan contended that there was uncertainty that science was not able to resolve despite accumulated evidence, so that it then relied on reason to adopt the measure. The Appellate Body rejected this argumentation by distinguishing a situation of "scientific uncertainty" from one of "insufficiency of relevant scientific evidence" which is covered by Article 5.7.91

The precautionary approach of the SPS Agreement does not operate without limitations, it must conform to the principle of proportionality or be proportionate to the likely harm that can result from the activity that is to be restricted. ${ }^{92}$ This has been an important and consistent element for the Appellate Body in making its analysis. One such analysis was made in the Brazil-Retreaded Tyres ${ }^{93}$ case concerning measures to ban the importation of used tyres from the EC to the Brazilian market. Brazil maintains that the ban was "necessary" to protect human, animal, or plant life or health within Article XX GATT 1994, and seeks to reduce accumulation, transportation, and disposal risks associated with the generation of waste tyres in Brazil. The Appellate Body found that the measure constituted discrimination and was inconsistent with Brazil's WTO obligations. In making its findings the Appellate Body considered the relevant factors particularly the importance of the interests or values at stake, the extent of the contribution to the achievement of the measure's objective, and its trade restrictiveness. ${ }^{94}$

The WTO has taken a rather cautious stance on the inclusion of the precautionary approach in the SPS Agreement. Measures are eligible to be classified as an SPS measure only if its objective is the protection of human, animal, or plant life or health. In addition, a measure must be designed to protect against either food-borne risks in which case human or animal life may be at stake, pest, or disease-related risks pertaining to human, animal or plant life or health, and must directly or indirectly affect international trade. ${ }^{95}$ The SPS measure must be based on a

\footnotetext{
${ }^{91}$ Gerstetter, above $\mathrm{n} 89$, at 11.

92 Wagner, above n 24, at 732.

${ }^{93}$ Brazil - Measures Affecting Imports of Retreaded Tyres WT/DS332/AB/R, 3 December 2007 (Appellate Body Report).

${ }^{94}$ Report, above $n$ 93, at [178].

${ }^{95}$ Wagner, above $\mathrm{n} 24$, at 740 .
} 
risk assessment with a level of scrutiny that is different for food-borne, pest, or disease related risks. In food-borne related risk only the potential for adverse effects on human or animal health need to be evaluated, while for pest or disease requires evaluation of the likelihood of entry, establishment or spread of the disease and of associated potential biological and economic consequences. ${ }^{96}$

Basically Member States are free to determine their own acceptable level of risk, which can be established using a quantitative or qualitative method, but measures adopted to prevent the risk must be ascertainable and not assumed. This confirms the requirement that a measure cannot be adopted without sufficient scientific evidence. ${ }^{97}$ It is important to note that risk assessment is not limited to risk ascertainable in a science laboratory operating strictly controlled conditions, but also risk in human societies as they usually exist, or the actual potential adverse effects on human health in the real world where people live, work and die. ${ }^{98}$ It is at this interval where the precautionary principle provides a qualified exemption to the requirement of the general rules. ${ }^{99}$ However in doing so, Member States must satisfy the four requirements which are inherent to Article 5.7 of the SPS Agreement, as reflected in the findings of the relevant cases above, as follows:

1. adopted with regard to a situation where relevant scientific information is insufficient;

2. imposed on the basis of available pertinent information;

3. seek to obtain the additional information necessary for a more objective assessment of the risk; and

4. review the measure accordingly within a reasonable period of time.

\section{Reconciling the Precautionary Principle and International Trade Law}

\section{A Identifying Areas of Challenges}

There are two general opposing views on the relationship between the precautionary principle and international trade law. One group is of the view that the precautionary principle is

\footnotetext{
96 Australia - Measures Affecting Importation of Salmon WT/DS18/AB/R, 20 October 1998 (Appellate Body Report).

${ }^{97}$ Wagner, above n 24, at 740.

${ }^{98}$ EC-Hormones Appellate Body Report [187].

${ }^{99}$ Wagner, above n 24, at 742.
} 
increasingly becoming relevant and provides a tool for making decisions to address environmental concerns on which there is insufficient evidence but where there is reasonable conviction of harm. The other group believes that incorporating the precautionary principle in trade and accommodating relevant measures in the WTO could lead to increased protectionism. The reality is that the current global situation needs a balance between the both. It is time to take the concept of sustainable development more seriously. Sustainability is perceived from an environmental as well as economic point of view, so we need to foster a condition where environmental and economic factors are mutually supportive and can sustain our existence for years to come.

It would be fair to say that the current state of the WTO Agreement, whose roots date back to the GATT 1947, is not too well-equipped to deal with the new challenges of the environment or environment-related trade activities. The WTO, although acknowledges the importance of safeguarding human, animal, and plant life or health, was established to promote trade. As such free trade must be maintained as far as possible by establishing rules to protect and ensure its sustainability. When these interact or conflict with environmental measures, it is commonly the trade rules that prevail. There is a strong focus on trade-promoting measures with little emphasis on social costs. ${ }^{100}$ Instead of having a general and consistent approach on environmental measures, the WTO looks at such on a case-by-case basis, particularly with regard to compliance with its rules.

In deciding its cases, the WTO DSB Panel or Appellate Body would generally use a close treaty interpretation to determine whether measures have satisfied the requirements to qualify as an exception. The term exception is because environmental measures, or in this case SPS measures, are rather difficult to implement without invoking the exceptions available in the agreements, or the rules that can only be utilized under exceptional conditions, such as Article XX GATT 1994 and Article 5.7 SPS Agreement. By nature it is difficult under WTO rules to implement these measures without derogating from obligations. Some measures are not implemented with having the said requirements in mind, but in becoming a dispute in the WTO, the exceptions are invoked to justify such measures. The Appellate Body in particular seems to have the view that the precautionary principle is not a general principle of international law,

${ }^{100}$ Wagner, above n 24, at 762. 
hence it does not award the precautionary principle the status of legally binding principle of international law. ${ }^{101}$

On the other hand, it is not without foundation, that there is fear of the precautionary principle used as a guise of environmental and health measures to mask protectionism. There are countries with high environmental protection levels that may attempt to apply restrictions on the imports of products which do not correspond to the environmental standards in force, or countries with high awareness who may subsidize their exports to increase the competitiveness of their industry that is overburdened by environmental protection regulations. ${ }^{102}$ They may also attempt to apply different custom tariffs to products depending whether the products were produced by taking into account environmental considerations or polluting the environment and in an unsustainable manner ${ }^{103}$, such as carbon taxing.

The lack of concrete definition of the precautionary principle also poses a difficulty in interpreting and implementing the principle in the context of trade. Even though it is included and referred to in a number international treaties, its actual meaning and content remains ambiguous, thus making it an unsuitable guideline for decision-making or can increase unchecked administrative discretion. ${ }^{104}$ The principle does not provide clear evidentiary basis or stipulates limitations for it application, which some also fear would lead decision-makers to respond to unfounded fears based on uncertainty and enables them to create worst case scenarios to justify banning useful activities. ${ }^{105}$ Others also noted that it is arbitrary to proceed on the assumption that the worst of numerous results will materialize as there is a lack of empirical basis for this assumption in the face of scientific uncertainty. ${ }^{106}$

\section{B Addressing Challenges and Recommendations}

Given the current interaction or friction between WTO rules and the precautionary principle, a reform would be a reasonable option to reconcile these two. This reform could take

\footnotetext{
${ }^{101}$ Gerstetter, above n 89, at 13 .

102 Hannes Veinia "Free Trade and the Precautionary Principle" (2003) Juridica International VIII $<$ www.juridicainternational.eu $>$ at 187.

${ }^{103}$ Veinia, above n 102, at 187.

${ }^{104}$ Herwig, above n 33, at 301.

105 Above n 33, at 301.

106 G. Majone "What Price Safety? The Precautionary Principle and its Policy Implications" (2002) 40 Journal of Common Market Studies 89, as cited in Herwig, above n 33, at 302.
} 
place within the WTO rules by amending the relevant Agreements. Turner emphasized this point by stating that:

...it will be necessary for the trade rules themselves to be amended...in order that they become part of the process of environment protection rather than purely part of a system of 'non-discrimination' and trade liberalization. ${ }^{107}$

Notwithstanding the arduous process of treaty negotiating and treaty making, amendments in the relevant agreements containing specific rules on environmental protection seems a reasonable approach. A more ambitious pursuit would be to formulate a specific agreement under the WTO dedicated to trade and environment that prescribes the conduct for environmentally-conscious trade.

Concerns for the sustainability of free trade and Member States' level of development can be addressed by providing requirements that environmental efforts must be conducted in a balanced and trade enabling manner, but that is less rigid than the existing rules. More importantly amendments are needed to ensure that there is room for Members States to adopt protection measures, not just a vague provision that acknowledges the right to adopt their own level of protection. Article XX GATT 1994 or Article 5.7 SPS Agreement may not suffice in justifying Member States' environmental measures so new rules need to include more precise ${ }^{108}$ and comprehensive formulation on how and when a Member may invoke such rules.

Starting talks for amendments in the WTO would require a new mandate. Proposals can be initiated in the relevant WTO body/committees, for example in the Committee on Trade and Environment (CTE). Providing the CTE with an additional task of coordinating and collaborating with the implementing bodies of MEAs may also strengthen its role in examining further the relationship between trade and environment with regard to the precautionary principle. Other important committees obviously include the TBT and SPS Committees which are tasked with administering the respective agreements and could serve as a forum to deliberate on the precautionary principle. In this respect, the WTO can also play an important role in defining, shaping, and maybe further down the line even encouraging the use of the precautionary principle. As an example, the European Union in 2000 submitted the EC's

\footnotetext{
${ }^{107}$ Stephen J. Turner A Global Environmental Right (Routledge, Oxon, 2014) at 58.

${ }^{108}$ Andrew D. Mitchell Legal Principles in WTO Disputes (Cambridge University Press, New York, 2008 ) at 31.
} 
communication on the application of the precautionary principle and the resolution on the use of the precautionary principle to the SPS and TBT Committees ${ }^{109}$ where the issue was debated and negotiated.

There are examples of cases where environmental protection measures have been accommodated in the WTO, such as in EC-Asbestos ${ }^{110}$ and the US-Shrimp ${ }^{111}$, which provides optimism that the WTO is not entirely indifferent to environmental concerns. The DSB Panel and Appellate Body have an important role to play in this matter. They are capable of interpreting measures 'in the light of contemporary concerns of the community of nations about the protection and conservation of the environment ${ }^{\prime 12}$ and in doing so be more inclined to give positive consideration to environmental protection instead of just establishing their analysis based on close treaty interpretation. They are also entitled to seek additional evidence and information or inputs on risks or hazards from outside sources to assist them in making their findings. Hence, they can gather as many data as they need, for example through 'amicus curiae' briefs from NGOs or other concerned parties, to understand the consequences on certain activities on the environment.

Under the Doha Declaration, the WTO is also to be active in coordination with MEAs secretariats ${ }^{113}$, so this mandate can be expanded to include a discussion on the precautionary principle. To date for example the WTO has collaborated with the United Nations Environmental Programme (UNEP) to produce a comprehensive report on climate change. ${ }^{114}$ The WTO is not an exclusive authority and is allowed to consult with other international organizations and NGOs. As a matter of fact other international organizations and NGOs are already part of the WTO process as observer members, such as the World Health Organization, UN Conference on Trade and Development, Codex Alimentarius Commission, World Organization for Animal Health and UN Framework Convention on Climate Change. The improved understanding of the

\footnotetext{
109 Gerstetter, above n 89, at 17.

${ }^{110}$ European Communities - Measures Affecting Asbestos and Products Containing Asbestos WT/DS135/AB/R, 5 April 2001 (Appellate Body Report).

${ }^{111}$ United States - Import Prohibition of Certain Shrimp and Shrimp Products WT/DS58/AB/R, 6 November 1998 (Appellate Body Report).

112 Above, n 111, at [129].

113 Wagner, above n 4, at 757.

114 World Trade Organization and UN Environment Programme, Trade and Climate Change (2009) $<$ www.wto.org $>$.
} 
WTO on environmental concerns and how trade activities can impact the environment can result in a more forward-looking WTO jurisprudence which is more adept at taking into account recent evidence of the risks that certain activities present and also of its objective to support sustainable development. ${ }^{115}$

Meanwhile, the precautionary principle could also be made more attuned to trade. Since the WTO relies so much on evidence, including on risks, maybe the precautionary principle itself needs to be subjected to risk-based and cost-benefit analysis so that its adverse and paradoxical effects can be identified and neutralized. ${ }^{116}$ Developing a guideline on the precautionary principle and trade could also prevent it from being invoked in support of protectionism. ${ }^{117}$ This would also help to clarify many issues on environmental law and trade law which may be interlinked or conflicting. The elements in Article 5.7 SPS Agreement could be a good foundation for developing such guideline. The criteria to be included in the guideline can consist of requirement to base measures on risk assessment, proportionality of action to the seriousness of risk and non-automatic justification for severely restrictive action, tendency to err on the side of caution due to scientific uncertainty, cost and benefit analysis of action and inaction, review in light of scientific development, and transparency of process. ${ }^{118}$

The linkages between trade and environment, and the current state of environmental degradation as a result of trade-related activities, merit a harmonized approach and governance that integrates the WTO rules and the precautionary principle. Consequently, the rules of the WTO need to be adjusted to incorporate the objectives of environmental protection including as reflected in the precautionary principle. As such, a reform of WTO rules through the amendments of existing Agreements would enhance WTO's role and effectiveness in addressing trade and environmental issues. Such reform could also improve the way in which WTO's Dispute Settlement Body manages dispute cases and be more facilitative to environmental concerns.

\footnotetext{
${ }^{115}$ Wagner, above $\mathrm{n} 4$, at 759 .

116 Lucas Bergkamp and Lawrence Kogan "Trade, the Precautionary Principle, and Post-Modern Regulatory Process: Regulatory Convergence in the Transatlantic Trade and Investment Partnership" [2013] EJRR 4.

${ }^{117}$ Ward, above $\mathrm{n} 7$, at 7.

${ }^{118}$ Above $\mathrm{n} 7$, at 7.
} 


\section{Conclusion}

The increasing concern on the impact of trade on the environment and the recognition that scientific evidence is not always sufficient in determining risks of certain activities has encouraged decision-makers to invoke and implement measures based on the precautionary principle. It remains however the subject of debate in the context of trade and how it interacts with the principles and rules of international trade law under the WTO. The debate is whether the two are consistent and compatible with one another given that they are governed by a different set of rules. The WTO recognizes Member States rights to determine their own acceptable level of risk and uses a precautionary approach in the SPS Agreement but does not recognize the precautionary principle as a general principle of international law. Views persist that incorporating the precautionary principle in trade and accommodating relevant measures in the WTO could lead to increased protectionism. Given the current global situation, there is a need to harmonize international trade law and environmental law. There are several options which can be explored to reconcile the WTO rules and the precautionary principle, such as amending the relevant WTO agreements, enhancing DSB's role, strengthening coordination with other international bodies, and attuning the precautionary principle to international trade law. 


\title{
BIBLIOGRAPHY
}

\author{
PRIMARY SOURCES
}

\section{A Cases}

European Communities - Measures Concerning Meat and Meat Products WT/DS26/AB/R and WT/DS48/AB/R, 13 February 1998 (Appellate Body Report).

Australia - Measures Affecting Importation of Salmon WT/DS18/AB/R, 20 October 1998 (Appellate Body Report).

United States - Import Prohibition of Certain Shrimp and Shrimp Products WT/DS58/AB/R, 6 November 1998 (Appellate Body Report).

Japan - Measures Affecting Agricultural Products WT/DS76/AB/R, 19 March 1999 (Appellate Body Report).

Japan - Measures Affecting the Importation of Apples WT/DS245/AB/R, 10 December 2003 (Panel Report).

European Communities - Measures Affecting Asbestos and Products Containing Asbestos WT/DS135/AB/R, 5 April 2001 (Appellate Body Report).

European Communities - Measures Affecting the Approval and Marketing of Biotech Products WT/DS291/R, 29 September 2006 (Panel Report).

\section{B International Treaties, Agreements and Declarations}

The Montreal Protocol on Substances that Deplete the Ozone Layer (open for signature 16 September 1987, entered into force 1 January 1989).

United Nations Rio Declaration on Environment and Development 1992.

Ministerial Decision on Trade and Environment LT/UR/D-6/2 (1994).

Marrakesh Agreement Establishing the World Trade Organization (signed 15 April 1994, entered into force 1 January 1995).

General Agreement on Tariffs and Trade 1994 LT/UR/A-1A/1/GATT/1 (signed 15 April 1994, entered into force 1 January 1995).

Agreement on the Application of Sanitary and Phytosanitary Measures LT/UR/A-1A/12 (signed 15 April 1994, entered into force 1 January 1995). 
Agreement on Technical Barriers to Trade LT/UR/A-1A/10 (signed 15 April 1994, entered into force 1 January 1995).

Understanding on Rules and Procedures Governing the Settlement of Disputes LT/UR/A2/DS/U/1 (signed 15 April 1994, entered into force 1 January 1995).

Doha Ministerial Declaration WT/MIN(01)/DEC/1 (2001).

The Cartagena Protocol on Biosafety to the Convention on Biological Diversity (open for signature 29 January 2000, entered into force 11 September 2003).

The Rotterdam Convention on Prior Informed Consent for Certain Hazardous Chemicals and Pesticides in International Trade (open for signature 10 September 1998, entered into force 24 February 2004).

The Stockholm Convention on Persistent Organic Pollutants (open for signature 22 May 2001, entered into force 17 May 2004).

Kyoto Protocol to the United Nations Framework Convention on Climate Change (open for signature 11 December 1997, entered into force 16 February 2005).

Hong Kong Ministerial Declaration WT/MIN(05)/DEC (2005).

SECONDARY SOURCES

A Texts

Andrew D. Mitchell Legal Principles in WTO Disputes (Cambridge University Press, New York, 2008).

Cass R. Sunstein Laws of Fear: Beyond the Precautionary Principle (Cambridge University Press, Cambridge, 2005)

Christian Joerges and Ernst-Ulrich Petersmann eds. Constitutionalism: Multilevel Trade Governance and International Economic Law (Hart Publishing, Portland, 2011)

Edith Brown Weiss, John Howard Jackson and Nathalie Bernasconi-Osterwalder eds. Reconciling Environment and Trade (2nd ed, Martinus Nijhoff, USA, 2008).

Fiona Macmillan The WTO and the Environment (Sweet \& Maxwell, London, 2001).

Markus W. Gehring and Marie-Claire Cordonier Segger Sustainable Development in World Trade Law (Kluwer Law International, the Netherlands 2005).

Miriam Haritz An Inconvenient Deliberation: The Precautionary Principle's Contribution to the Uncertainties Surrounding Climate Change Liability (Wolters Kluwer, Alphen aan den Rijn, 2011) 
Mitsuo Matsushita, Thomas J. Schoenbaum and Petros C. Mavroidis The World Trade Organization: Law Practice, and Policy (Oxford University Press, New York, 2006).

Nathalie Bernasconi-Osterwalder, Daniel Magraw, Maria Julia Oliva, Marcos Orellana, and Elisabeth Tuerk Environment and Trade: A Guide to WTO Jurisprudence (Earthscan, London, 2005).

Nicolas de Sadeleer ed. Implementing the Precautionary Principle: Approaches from the Nordic Countries, EU and USA (Earthscan, London, 2007).

Peter Van den Bossche and Werner Zdouc The Law and Policy of the World Trade Organization (Cambridge University Press, New York, 2013).

Simon Baughen International Trade and the Protection of the Environment (RoutledgeCavendish, London 2007).

Stephen J. Turner A Global Environmental Right (Routledge, Oxon, 2014).

W. Bradnee Chambers Interlinkages and the Effectiveness of Multilateral Environmental Agreements (United Nations University Press, Tokyo, 2008).

WTO Secretariat The Legal Texts: The Results of the Uruguay Round of the Multilateral Trade Negotiations (Cambridge University Press, New York, 1999).

WTO Secretariat The WTO Dispute Settlement Procedures (Cambridge University Press, Cambridge, 2003).

WTO Secretariat A Handbook on the WTO Dispute Settlement System (Cambridge University Press, New York, 2004).

B Articles

Linda Cameron "Environmental Risk Management in New Zealand-Is There Scope to Apply A More Generic Framework?” (July 2006) New Zealand Treasury Policy Perspectives Paper 06/06.

Lucas Bergkamp and Lawrence Kogan "Trade, the Precautionary Principle, and Post-Modern Regulatory Process: Regulatory Convergence in the Transatlantic Trade and Investment Partnership" [2013] EJRR 4.

\section{Internet Resources}

Abdolhossein Shiravi and Azam Ansari "Precautionary Principle in the International Trade Regime: A Careful Look at the WTO SPS Agreement" < www.biconpro.com>.

Christiane Gerstetter and Matthias Leonhard Maier "Risk Regulation, trade and international law: debating the precautionary principle in and around the WTO" (2005) Transtate Working Papers No. $18<$ www.econstor.eu $>$. 
European Union Communication on Precautionary Principle "Commission adopts Communication on Precautionary Principle (2 February 2000) <www.gdrc.org>.

Halina Ward "Science and Precaution in the Trading System" (2002) Seminar Note $<$ www.iisd.org $>$.

Hannes Veinia "Free Trade and Precautionary Principle" "Free Trade and the Precautionary Principle" (2003) Juridica International VIII < www.juridicainternational.eu>.

Lawrence A. Kogan "The Precautionary Principle and WTO Law: Divergent Views toward the Role of Science in Assessing and Managing Risk" (2004) Seton Hall Journal of Diplomacy and International Relations $<$ www.kms2.isn.ethz.ch $>$.

Markus W. Gehring and Marie-Claire Cordonier Segger "Precaution in World Trade Law: The Precautionary Principle and its Implications for World Trade Organization" (2002) Research Paper $<$ www. cisdl.org $>$.

Markus Wagner "Taking Interdependence Seriously: The Need for a Reassessment of the Precautionary Principle in International Trade Law" (10 September 2012) $<$ www.papers.ssrn.com>.

Natasja Borjeson "WTO, GMO and the Precautionary Principle-the conflict between trade liberalization and environmental protection" (2004) Soderton Hogskola University College $<$ www.diva-portal.org $>$.

National Toxics Network Inc. "The Precautionary Principle Gets Real” <www.oztoxics.org>. 